\title{
The Effect of Death on Dissolution of Marriage Contract with Emphasis on Presumed Death
}

\author{
Hasan Mohamadi Ramghani ${ }^{1}$, Mohammad Roshan ${ }^{2} \&$ Mohsen Najafi Khah $^{3}$ \\ ${ }^{1}$ Higher Institute of Research and Training in Management and Planning, Tehran, Iran \\ ${ }^{2}$ Shahid Beheshti university, Tehran, Iran \\ ${ }^{3}$ Tarbiat Modares University, Tehran, Iran \\ Correspondence: Hasan Mohamadi Ramghani, Higher Institute of Research and Training in Management and \\ Planning, Tehran, Iran.
}

Received: September 4, 2016

Accepted: October 2, 2016 Online Published: December 29, 2016

doi:10.5539/jpl.v10n1p219

URL: http://dx.doi.org/10.5539/jpl.v10n1p219

\begin{abstract}
The dissolution of the marriage contract is either intentional or compulsory. The intentional dissolution basically takes place with divorce or termination application. But, the unintentional or compulsory dissolution means a marriage contract is dissolved automatically and without the will of the parties. The most important causes of unintentional dissolution include termination, death, expiration (in temporary marriages) and... which marriage contract can be dissolved by the occurrence of these and some other special causes. One of unintentional marriage dissolution causes is death. Death is divided into three groups of natural death, presumed death and constructive death. Iran's civil law has not pointed directly to constructive death, but beside other categories states its conditions and ordinance. There is no doubt that natural death triggers a marriage contract to be dissolved. There is disagreement among experts of Islamic rules and jurists on this matter if presumed death can dissolve a marriage or not. But, with study of legal rules related to missing person and the effects of the judgment rendered for presumed death, it seems that presumed death can dissolve the marriage contract too. And, the divorce application sets out at article 1029 of Iran's Civil Law relates to an occasion which inheritors have not applied from the court to issue a presumed death judgment.
\end{abstract}

Key words: Dissolution of marriage, presumed death, termination of marriage, missing person

\section{Introduction}

Dissolution of contracts has different forms. Thus, every contract can be dissolved by one of dissolution causes, which include termination, rescission, automatic cancelation, death, expiration and dispense with remaining term, some of which are intentional and some other unintentional. All legal experts believe that one of unintentional causes of marriage dissolution is death. The main question is that what effect really death has on marriage dissolution. For more true response, first we should study different types of death, and then, the effect of death on all contracts will be analyzed. Whenever the issue of contract dissolution, whether intentional or unintentional, is raised, the legal condition of contracts with respect of existence should be discussed. Based on the existence matter, contracts are divided into two groups; binding contracts and revocable contracts. The effect of death on binding and revocable contracts can be different. In revocable contracts, death of one of the parties, according to Article 954 of the Civil Law, causes the contract to be dissolved. While, in binding contract, death of one of the parties leaves no effect on the contract. But in a marriage contract, regardless being binding or revocable, as the personality of the parties is the main cause of the contract and living of parties is both the cause of contract occurrence and contract existence, so if one of the parties dies, the marriage contract is dissolved. But, this precision is only about natural death and presumed death doesn't enjoy such consensus among jurists. Thus, the second question is raised here, noting that there is no express about the effect of presumed death on marriage contract in law, whether such death can really dissolve the marriage contract? The presumption which seems to be true is that with considering Iran's corpus Juris death causes the marriage contract to be dissolved and there is no difference between natural and presumed death. In fact, the legislator does not have any express assertion about natural death, but nobody challenges this matter that natural death dissolves the marriage contract. For inferring this presumption, we firstly discuss different types of death and their effects on contracts on the basis of binding or revocable nature of contracts. And then, given the disagreement existing among jurist about presumed 
death, we study the effect of presumed death on dissolution of the marriage contract.

\section{The Dissolution of Marriage Contract by Death}

Death can be considered as one of unintentional causes of marriage dissolution. As death is categorized into three groups of natural, presumed and constructive death, thus we discuss different types of death in the first chapter, and then in next chapter we analyze the effect of death on binding and revocable contracts and also those contracts being binding for one side and revocable for another.

\subsection{Types of Death and Their Effects}

In this chapter, different types of death and their effects are studied and then this issue is analyzed whether effect of all deaths is the same or different.

\subsubsection{Types of Death}

\subsubsection{Natural Death ${ }^{1}$}

The death phenomena are a matter that can be discussed and studied from different points of view. From biological and medical viewpoint, it can be explained as a state which the active organization of the body protecting its life fails to work. This approach views human body only from physical, material and the five senses aspect. Thus, it knows the signs of death as stop of brain, heart and organs' functions and reduce to zero body temperature. This approach never points to exit of soul from body (Khameneiee, 2006).

But from a philosophical viewpoint, death is explained as eternal separation of the soul which causes the natural order of the body to be disrupted and it faces to disorder. Philosophers compare death and exit of soul from body to someone whose home has been destructed and forced to leave it and seeks another shelter. In spite of this type of death, which is called a natural death, philosophers recognize another type of death, which don't occur by failure of the natural order of the body, but incidents or intentional or unintentional acts of humans trigger it. This type of death is called an unnatural death, which the soul's home (body) is destructed by incidents and soul leaves body inevitably (Khameneiee, 2006).

Molasadra, the Iranian famous philosopher, has stated a new definition of death. After denial beliefs of biologists and doctors, which believe death is effected of failure of body function, pointing to two natural and unnatural deaths, he defines death as a release of the soul from bind of the body due to its perfection and needlessness to the body. In philosophical explanation of this belief, he asserts that the human soul is made from material and arises from body at first. But along with body growth, it forwards separate way for perfection. A perfection which does not stop with the beginning of oldness and negative growth of the body and continues its perfection growth. In fact, the soul has no oldness and entropy like body (Emami, 1996).

Anyway, the existence of a natural person is ended by death. A person loses its legal personality by death and cannot have any right and duty like alive persons. Notwithstanding, dead body of humans deserves to be respected, so it must be buried and according to Islamic ordinances and legal rules, disinterment is considered as an offence (Al-Ameli, 1982, p: 385).

\subsubsection{Constructive Death}

Despite natural death, there is another type of death called constructive or civil death, which was common in some legal systems of the world. In Islamic law, based on famous speech, the terms of constructive death are used only for a person whose father is a Muslim, but he himself renounces Islam, which such person is sentenced to death penalty, unless she was a woman. If such person remains alive, he will be regarded as a dead. His repentance will not be accepted. He will lose his legal personality and as a result, his properties will be divided among his heritors. His marriage will be dissolved and his wife can marry after expiration of the viduity period of death. But if that person is a woman, her repentance will be accepted and if she doesn't repent, she will be sentenced to life imprisonment (Al-Ameli, 1995, p: 234). Modern law does not recognize constructive or civil death, but a legislator introduces another legal institution which is called presumed death (Al-Ameli, 1982, p: $385)$.

\subsubsection{Presumed Death}

Presumed death is related to someone who has had a long absence and his living is doubtful. ${ }^{2}$ In this case and

\footnotetext{
${ }^{1}$. There is a type of death called voluntary death, which it means abandonment of the world and its enjoyments and refusal of what soul needs and disobedience of commanding to evil soul. Thus, such death of pious reveals by death of what occurs only for a dead person. This intentional death beside the natural death are interpreted as small resurrection. (Samadi Amoli, Davoud, the explain of heart book, Rooh-o-Iman publication, $2^{\text {nd }}$ Vol. first edition, p: 10). This writing does not deal with such death.
} 
noting to legal conditions set out in law, the judgment of presumed death is rendered. Presumed death is related to the missing person (Ibid). As the main issue of this writing is about presumed death, so we discuss briefly the conditions of presumed death's occurrence. The presumed death judgment is possible only for missing person. The missing person is an expression which legislator has applied it many times in civil and probate matters law and it indicates to a person who has been far from his residence and place of abode for a long time and there are not any signs of him. In Islamic jurisprudence, such absence is said interrupted absence too, and someone who has been absent in this way is also called person with unknown whereabouts. Of course, the terms of absent person have general meaning and refers to all persons who don't attend at a certain place. And, the application of this term in regards meaning can be interpreted on the basis of general application and special intention, for example, all persons who are absent for any reasons from court session and are at other certain place, or, persons of unknown place of abode which some news from them have been achieved, are out of scope of this definition (Ibid). Given the Article 1011 of the Civil Law, three terms are required the legal concept of the missing person to be occurred. They include absence from legal residence, expiration of a relative long time and lack of any news of life or death. If all three terms exist, the concept of the missing person is realized, otherwise, it is not occurred.

\subsubsection{The Effects of Death}

With occurrence of each type of death the certain legal effects are produced. The first effect is that heritors are determined. According to Article 867 of the Civil Law, death, whether natural or presumed, triggers heritage to be realized, and according to Article 875 of the Civil Law, the condition of heredity for heritors to be alive when legator is dead. According to Article 231 of probate matters law, death, whether natural or presumed, causes debts to become mature. And finally, a woman must keep viduity period after death of husband. Beginning and calculation of this period start from date of husband's death. If a woman is informed of such date with delay, according to famous speech, the calculation of viduity period starts from the date woman is informed. In respect of constructive death, there is no difference between constructive death and presumed death with regard in effects, although the law is silent about constructive death.

Thus, from effect point of view, natural death and presumed death don't differ with each other at all and basically presumed death is regarded as natural death and until the judgment of the court is not violated, all effects of natural death will be burdened to presumed death. In fact, until there is no evidence to prove that the judgment of the court about issuance of the presumed death for someone is untrue, presumed death will be considered as natural death and all effects of natural death will be burdened to presumed death.

\subsection{The Effects of Death on Contracts}

Before discussing the effects of death on contracts, we will study contracts from existence viewpoint which puts them into two categories of binding and revocable contracts. In Civil Law, legislator explicitly states that some contracts are binding contracts, for example contract of sale at Article 457 and contract of settlement at Article 760 , and any other contracts, like lending contract at article 638 and contract of deposit at article 611, are revocable contracts, and some contracts, including mortgage contact at Article 787, are binding for one side and revocable for other side. For other types of contract, law takes silence position, but according to opinion of jurists and experts of Islamic rules and also based on articles of 10 and 219 of Civil Law, they should be regarded as binding contracts. As the effect of death on contracts depending on binding or revocable contracts are different, thus in this chapter, contract dissolution by death is studied by considering above mentioned contract categorization.

\subsubsection{Dissolution of Binding Contract by Death of a Party}

One of dissolution causes is automatic cancelation. Sometimes an incident is occurred by which law renders a judgment for contract dissolution. In fact, there is no intention and nobody wants to dissolve the contract. This dissolution is called "enfesakh" or automatic cancelation. Of course, in some case, the parties agree if a certain incident occurs, the contract comes to termination. For example, if the buyer comes to his own city during next two months, the contract of lease will be terminated. But, binding contract basically is not dissolved by death and if one of the parties dies, the contract will not be affected. Thus, the death of one of parties can't disrupt contract and the dead person's legal representative will be obligated to contract. For instance, in the contract of sale, the obligations of seller and buyer are not affected by the death of one side of the contract (Katouzian, Legal Actions, 2006, p: 20). But in certain occasion, like when stewardship condition is made, the death of one party will result

\footnotetext{
${ }^{2}$. Article 1011 of Civil Law asserts that a missing person is someone who has passed relatively a long time from his absence and there is not any signs of him at all.
} 
in dissolution. Or, when the personality of the parties is the main cause of contract or living of the parties is the cause of contract existence, death of a party will terminate contract, although the contract is a binding one. Thus, living of the parties is the occurrence cause of all contracts, but it is the existence cause of some contracts.

\subsubsection{Dissolution of Revocable Contract by Death of a Party}

So, revocable contract refers to those contracts which without right of cancelation it can be dissolved essentially and according to the letter of the law. ${ }^{3}$ With respect to automatic cancelation based on law, as the Article 954 of Civil Law states, revocable contracts can be dissolved by death, insanity and foolishness, if the growth is valid. Thus, according to this article, the death of one side of a revocable contract can dissolve it (Katouzian, 2001, p: 156).

2.2.3 Dissolution of Those Contracts Which Is Binding to One Side of the Contract and Is Revocable to Another by Death

According to Article 187 of the Civil Law, a contract can be binding to a party and revocable to another party. It means the contract can be dissolved by one of two parties' will and non-cancelable by the other side of the contract. Among specific contracts, there are two examples which can clarify this assumption. The mortgage contract (Article 787 of Civil Law) which is revocable to the mortgagee and binding to the mortgagor, and the surety contract which is binding to bail bondsman and revocable to the beneficiary of a suretyship. With regard in legal dissolution, the conditions of revocable contracts are not burdened on these contracts, because they are not canceled by death and insanity of each side of the contract, even by death and incapacity of those whom contract is revocable to them, like mortgagor and bail bondsman, and the contract continues its legal life. As Article 788 of Civil Law states, mortgage contract is not dissolved by death of a party and rights and duties arisen from the contracts will be transferred to the dead person's heritor. ${ }^{4}$

But in surety contract, we should deal with death of bail bondsman and beneficiary of a suretyship separately. In fact, a surety contract is not disrupted or dissolved by the death of a bail bondsman. But if bail bondsman dies all assets of dead persons are transferred to his heritor, so bailment continues its legal life and the beneficiary of the suretyship is obligated against the new possessors of the assets to carry out his duties. As Article 784 of Civil Law states' death of bail bondsman does not cause the beneficiary of surety ship to be discharged (Katouzian, 2013, p: 238).

With the death of principal of suretyship contract, the subject of the beneficiary's obligation loses its relevance, because such obligation is connected with the recalling of principal and is not related to his debt that it should be transferred to heritor. Thus, there is no subject for the recalling after death of principal (Ibid).

Civil Law has not stated any rules for the death of the beneficiary. But as the obligation is only to recall and the right, which bail bondsman has and is related to the principal not to his properties, so the direct effect of the contract is only obligation to recall which is belonged to the beneficiary. Therefore, the obligation to recall pertains to beneficiary's personality and his spiritual dominance and relations to principal make possible the recall. But, if the beneficiary is unable or does not want to recall principal and then he dies, the debt is cleared from his heritors (Ibid). The surety contract is not terminated by the incapacity of parties like insanity and Civil Law does not have any regulation on this matter, although it is thinkable.

\section{Dissolution of Marriage Contract by Death}

\subsection{Position of Marriage Contract in Categorization of Contract on the Basis of Existence}

The legislator has never pointed to binding or revocable nature of the marriage contract, which all jurists believe that the marriage contract is a binding contract. In fact, what is more compatible with the nature of marriage is to be binding. But as contracts are divided into binding and revocable on the basis of contract existence and the possibility of termination by one will of parties, therefore the marriage contract is like biding ones, because it is not cancelable without presenting legitimate causes by the parties. But, as husband can cancel the marriage contract without reason, although by other legal action except termination (divorce), whenever he wants, the contract is like biding ones. But as wife in certain cases cane presents divorce application, it resembles to those contracts which is binding to one side and revocable to another. Given the features and cases of contract dissolution, particularly marriage contract, it is better that it is recognize binding contract for revocable and

\footnotetext{
3 . As the Article 186 of Civil Law states, revocable contract refers to those contracts that each party can cancel it whenever wants.

${ }^{4}$. Article 788 of Civil Law states that the mortgage contract is not terminated by death of the mortgagee or mortgagor, but if the mortgagor dies, the mortgagee can apply that the mortgage comes into possession of a third person who is specified by agreement of heritor. If there does not exit such an agreement, the regarding third person is determined by sovereign.
} 
binding for a wife (Katouzian, 2003, p: 213).

\subsection{Effect of Natural Death on Dissolution of Marriage Contract}

As mentioned, the marriage contract is revocable for husband and binding for wife and also, binding contracts are dissolved by death but binding contracts are not influenced by death. But the rules of binding contracts are implemented for those contracts which are binding to a party and revocable to another one. According to the features of the marriage contract, one of unintentional causes of dissolution contract is death, even if it is considered as a binding contract. ${ }^{5}$ Because the personality of the parties is the main case of the contract and living of the parties is important and necessary both for the conclusion and the existence of the contract. Of course, the legislator has not pointed to death in Article 1120 of the Civil Law as listing the causes of dissolution of the marriage contract. But there is no doubt that one of parties' death leads to the dissolution of the contract. It is possible that the legislator has not named death as dissolution causes in Article 1120 because it is so evident (Safaee, 2008, p: 181). Thus, one of parties' death, whether in permanent or temporary marriage, will result in dissolution of marriage contract.

\subsection{Effect of Presumed Death on Dissolution of Marriage Contract}

In respect to effect of presumed death on dissolution of the marriage contract, there is disagreement among jurists and experts of Islamic rules. Some believe that one of marriage termination cause is absent husband, which can be led to issuance of presumed death by the court. By this order, the marriage contract will be dissolved and wife must keep period widowhood period. But, some believe that presumed death cannot influence the marriage contract. Therefore, in this part, we discuss two above mentioned groups' opinions.

\subsubsection{Opponents' Beliefs on Effect of Presumed Death on Dissolution of Marriage Contract}

This theory states that presumed death has no effect on the marriage contract. Its believers infer that the legislator has regulated missing person's management of financial and marital affairs under two separate legal systems and made special rules for them. Regulations pertaining to presumed death are related to financial affairs and protection of his properties, because representative of an absent or appointed trustee is responsible for managing only financial affairs and matters related to incapable under guardianship, while the matter of matrimony is a separate issue and the absent person's wife does not require benefactor, except she is an incapable, and this relation is dissolved only through termination or divorce (Safaee, 2008, p: 67).

The matter of what should be carried out before issuance of a presumed death order is separate from the effect of such death. Selecting a trustee for managing absent person's financial affairs or granting temporarily possession of the properties to heritors by their application are among those matters which can be done before issuance of a presumed death order which are independent from the effect of presumed death. We cannot infer that as most of the regulations pertaining to measures which can be done before the presumed death order is related to financial matters, so all conditions of death can be transferred to the presumed death assumption except marriage dissolution. Making exception needs the exact letter of law, which Civil Law has never expressed that presumed death has no effect on the marriage contract.

As studied, marriage dissolution is either intentional or compulsory and termination and divorce are regarded as intentional causes of marriage dissolution. While death is known as an unintentional cause of marriage cancelation, therefore, the marriage contract is not dissolved only by termination and divorce and death, whether natural or presumed death, can forcibly dissolve the marriage contract. Thus, marriage contract can be dissolved by some causes, including sworn malediction, heresy, unbeliever woman converting to Islam, sex change and death. Therefore, divorce and termination are not only causes of marriage dissolution.

The second reason of opponents about the non-expansion of presumed death conditions to marriage dissolution is that when a presumed death order is issued, the properties of absent person come to absolute possession of heritor and wife's portions of inheritance is paid, but there is not sufficient reasons by which a matrimonial relationship can be terminated. Because, presumption of death can be effective in financial affairs by legislator assertion and regarded as a cause for occurrence of inheritance and its expansion to matrimony matter needs legitimate reason and the exact letter of law.

Some jurists have challenged the above mentioned idea. They say how it is possible, we consider an absent person as dead and divide his properties and even pay his wife's portions of inheritance, but believe the matrimonial relationship has not been disrupted. How can this incompatibility be justified? Then, they response

\footnotetext{
${ }^{5}$. As husband can dissolve the marriage contract whenever he wants and wife is able to cancel it only in some certain cases, so it is understood that the marriage contract is binding to wife and revocable to the husband.
} 
to themselves, assert that disruption of a matrimonial relationship needs a legal cause which legislator has expressed them obviously and imitatively, which does not include presumed death. In management of financial affairs provided by application of heritor or beneficiaries and led to the presumed death judgment, there is no relation with matrimony. Because the wife of absent person may be not interested in such separation and nobody can enforce her to keep widowhood period without her application. Islamic rules also state when an absent person has properties from which his wife maintenance is paid or his guardian manages his wife's affairs and pays her life's costs, it is obligatory for a woman to keep patience and wait for her husband and she is not allowed to marry except when she knows her husband's death or divorce. So, when it is said that according to court's judgment a woman has kept widowhood period and after expiration of the period, matrimonial relationship has been interrupted and she is no longer known as a married woman and she can remarry, it should be said that based on law, all measures have been taken in respect to presumed death will be ineffective, except actions which have been carried out for protecting and managing his properties. ${ }^{6}$ One of such measures is keeping widowhood period and subsequent acts which based on this article should be ineffective (Qasemzadeh, 1996, 95).

Although the above mentioned challenge is true, but its response is a little problematic that we try to reply it. There is no doubt that interruption of a matrimonial relationship requires a reason, but whether death is one of dissolution causes of marriage contract or not. If we consider death as a dissolution cause, as mentioned earlier, accepting that marriage can be dissolved by types of death cannot lead to expansion of marriage's dissolution causes. Also, in Iran's Civil Law, the effects of presumed death has not limited to financial affairs and all effects of natural death are burdened to presumed death and excluding a certain case needs a reason, not including to its effects. So, contrary to the above presented theory, it should be inferred that with the issuance of presumed death judgment, all effects and conditions of natural death are burdened to presumed death, and if a certain case is excluded from such judgment's effects and is made exception, it needs exact letter of law. While, there is no regulation which excludes marriage from the effects of presumed death.

In respect to the assumption which Islamic rules assert that a wife should wait for her husband and she cannot remarry, it relates to an occasion that the presumed death judgment has not yet issued. Because if the presumed death judgment is rendered all properties of an absent person will be divided among heritors and there will not exist any properties by which wife's maintenance is paid. It may be said that an amount of properties will be left aside for the wife's maintenance and the remaining will be divided among heritors. But this idea is rejected. Because, firstly, how long has the wife's maintenance been left aside? Secondly, if the regarding amount was ran out and husband did not come, what wife would do? At first, for leaving aside an amount of property and not dividing it among heritors for future maintenance of wife requires the letter of law, while there is no such assertion in the law. Furthermore, future maintenance has not been turned into a debt which can be recovered from absent person's properties and remaining assets can be divided among heritors. Thus, after the issuance of presumed death judgment, there will not be remained any properties from which wife's maintenance can be paid. It may be said that in the case of lack of property after presumed death judgment; wife refers to court and applies divorce. But, is it really possible that a ruler who previously has presumed death of husband and issued his death judgment, accepts his wife's divorce application which it means the ruler presumes living of husband and wants in the representation of husband to divorce his wife? At least, acceptance of this idea by the ruler is much thinkable (Safaee and Emami, 1998).

\subsubsection{Theory of Effect of Presumed Death on Marriage Dissolution}

According to this theory, as the presumed death judgment results in occurrence of heritage and property division, it also dissolves the matrimonial relationship and woman can keep widowhood period and after expiration of the period woman can remarry. In justification, jurists express below reasons:

Firstly, the judgment of presumed death is regarded as real death, because such judgment is issued when this person is not usually alive. ${ }^{7}$

Secondly, with acceptance of this theory and its implementation, a harmony is made between financial and non-financial affairs of absent person and is avoided earlier mentioned duality.

In Islamic rules, conditions pertaining to the financial affairs of absent person and viduity matter are presented and studied separately in heritage and divorce books respectively. It may be for this reason there is no assertion about expansion or non-expansion of presumed death to matrimonial relationship. But, in matters relating to the

\footnotetext{
${ }^{6}$. Article 161 of probate matters law

7. Article 1019 of Civil Law
} 
viduity of wife's absent person, which is usually presented in debates of viduity of death, we face to some sayings and ideas which they can be used for justification of this theory. For example, some experts of Islamic rules name a type of viduity which is kept by judgment of ruler and without the exercise of divorce. It means ruler allows a woman to keep viduity period without the issuance of presumed death judgment. Of course, the duration of such viduity is also four months and ten days. It should be noted that at first rules specifies a four-year research for finding missing persons, and when the research was carried out as said in the books of Islamic rules and the person was not found, the ruler would order woman to keep viduity period. Of course, the order of ruler for keeping viduity should not be mistaken with the presumed death judgment (Khansari, 1985, $563)$.

According to this theory, wife of absent person, like other heritors, has the right of inheritance (one third or one fourth) and without divorce is exercised she keeps viduity period and after expiration of this period she can marry with another person.

But, absent person may return after the issuance of presumed death judgment, which in this case some other problems reveal. Firstly, if he returns before or after expiration of viduity period and before woman's remarriage, the matrimonial relationship is not interrupted and he can continue his marital life with his wife. Because, by return of absent persons, the nullity of presumed death and keeping viduity period will reveal and it is found that the matrimonial relationship is also established.

If the absent person comes back after expiration of viduity period and wife's remarriage, in this case, the nullity of presumed death judgment and viduity period, which wife has been kept based on the presumed death judgment and her remarriage will be obvious and indisputable. Because, as mentioned in previous assumption, all measures have been done based on the presumed death judgment which its nullity is proved by return of absent persons, so all effects should be eliminated (Qasemzadeh, 1996, p: 93).

It is necessary to be said that this situation should not be mistaken with the assumption which wife is divorced according to law. In this case, the matrimonial relationship is interrupted and dissolved and when viduity period is expired, the husband will be unable for revocation, whether woman remarries or not. Thus, by revealing the nullity of a subsequent marriage, it is appeared that wife is still in matrimonial limitation of previous husband and the relationship has not been dissolved. Of course, children resulted from subsequent marriage will be regarded as an ex-reputive marriage issues, which are legal issues and don't face any problem from legality viewpoint, although, with regard in customs, spiritual and educational matters, they have serious challenges (Ibid).

Considering all ideas of Islamic rules experts and jurists and regulations about absent person and the presumed death judgment and the effect of death on marriage dissolution, it is inferred that the presumed death judgment can dissolve the marriage contract. Like the divorce judgment, which is issued by the court if wife applies, it should be appeared in court that absent present is not alive and it can be said that presumed death is the prelude to the divorce judgment and court should observe all formalities specified for presumed death. Therefore, it seems the divorce application is related to that assumption which the presumed death judgment has not been issued. And the reason which wife can apply for divorce after expiration of the four-year period is that she waits until the presumed death is issued, which the marriage automatically will be dissolved, but if there was no application for presumed death, she could apply for the divorce judgment. In that occasion which Islamic rules experts believe it is better wife waits, it seems it relates to the assumption which the presumed death, for any reason, whether heritors are not tended or there is no heritor, but wife, is not applied and the judgment is not issued, so the experts say that if there is a property from which the wife's maintenance can be paid or someone takes in her maintenance, wife like other heritors wait and does not apply for a divorce.

Regarding this idea that presumed death can dissolve the marriage contract, if the husband comes back before expiration of the viduity period, because divorce has not been registered, he can continue his marital life with his wife. But after the expiration of viduity period and registration of divorce, the revocation is not possible. Because, the sole return of absent persons cannot make invalid a formal document. And if the wife remarries, the husband's revocation will encounter with a legal obstacle. Because, according to the presumed death judgment, the woman had not been in matrimonial limitation of anybody at the time of her remarriage and her marriage contract with her previous husband had been dissolved by the presumed death judgment. In respect of juridical acts, rules and conditions of the time, which such acts are established, must be considered. Transactions are dealt with in this manner. Presume that person A sells a car to person B, and they make rescission the transaction. If the buyer sold the car, the rescission would not be disrupted. And it will be regarded as a kind of constructive waste. Of the presumed death judgment and wife's remarriage, although third persons can request the judgment 
to be cancelled, but the previous marriage of a woman has been dissolved by the presumed death judgment and such a judgment is a formal document. Thus the marriage, occurred based on this judgment and before husband returns, is true. Contrary to some jurists, after issuance of presumed death all effects of judicial acts done prior to such judgment will not be fully eliminated. With regard of puppetries, they, like natural death assumption, come to absolute possession of heritors. And, heritors will be considered as the possessors of absent person's properties by the issuance of presumed death judgment. ${ }^{8}$ Thus, the effects of presumed death continue until the judgment is not countermanded.

After issuing presumed death and transferring the properties to heritors, if the absent person returns, based on Article 1027 of the Civil Law, the heritors must return properties to him. But they are not responsible for those properties which have been wasted or existed from their possession. Because, at the time of waste of transfer, they have been the possessors of the properties and their possession have been possessed (Safaee and Qasemzade, 2005, p: 76). Therefore, in the case of absent person's return, although he can object to the presumed death judgment, but it is not possible that all circumstances restore to the state which the presumed death judgment has not issued. And those judicial acts which were carried out at the time of validity of the presumed death judgment would be true, including remarriage of the wife. So, it seems that if a wife has not remarried and husband returns, the presumed death judgment can be cancelled and they continue their marital life. But if the wife has remarried, as at the time of the subsequent marriage and according to presumed death judgment, the previous marriage of the wife was dissolved, the return of a husband would be ineffective on the validity of her following marriage.

These effects are also burdened with natural death. Imagine a woman surmises that her husband has been died. Because a corpse is found that it resembles to his husband very much and as his face has been burned, he cannot be truly identified. The certificate of death is issued and the woman keeps viduity based on it. If the husband returns, the effects of the death certificate will be neutralized. But it will not be done automatically. In both natural and presumed death, the sole return of absent persons cannot make ineffective the court's judgment and he should take action to cancel the judgment through one of legal manners which is an objection of third persons. Since, heritors and wife invoke to the presumed death judgment, so it will be valid until effects have not been cancelled out.

This is also proved applicable for natural death. In fact, after the absent person returns, he must refer to court and apply nullity of death certificate. Although, he is alive, but, he is presumed dead legally and even he cannot use his identity papers.

\section{Conclusion}

Death is one of unintentional causes of marriage, and basically it causes a revocable contract is dissolved. But, a binding contract is not terminated by death and just in some exceptional cases, death can cancel the contract. The legislator has not pointed to binding and revocable nature of the marriage contract, since, all jurist believe that marriage is a kind of binding contract. But, according to the existence of contracts and possibility of contract termination by one of the parties' will, they divided all contracts into two groups of binding and revocable contracts. As, marriage contract cannot be dissolved without legitimate reason and in fact, it is not cancellable, it is like binding contract. But, as man can dissolve the marriage whenever he wants, although through a judicial act except termination (divorce), and woman can apply for divorce only in some certain cases, thus it is inferred that marriage belongs to a type of contracts which are binding to a party and revocable to another. And regarding to features and cases of contracts dissolution, particularly dissolution causes of marriage, it is better that the marriage is considered as binding to man and revocable to woman.

The marriage contract is also dissolved by death. Of course, it is independent from being binding or revocable contract. It is for that reason parties' personality is the main cause of the contract and living of the parties is the cause of contract existence. So, if one of the parties dies, the contract will be dissolved. There is no difference between types of death. It can be said that presumed death, like natural death, can dissolve the marriage contract. And, it is not reasonable that court once presumes the absent person as dead and issues the presumed death judgment for him and then supposes him alive and divorce his wife.

\section{Resources}

Al-Ameli, Zein-o-din Al-Jabaiee. (1982). famous as Shahid-e-Sani, Al-Roza-al-Bahiya in explanation of al-Loma (Vol. 6, 1st ed.). Darolhadi Publication.

Al-Ameli, Zein-o-din Al-Jabaiee. (1995). famous as Shahid-e-Sani, Masalek-al-Afham (Vol. 8). Science of Islam

\footnotetext{
${ }^{8}$. According to Article 160 of probate matters law, after issuance of presumed death, all assurances got from the trustee or heritor is terminated.
} 
publication, Qom.

Emami, S. H. (1996). Civil Law (Vol. 4, 17th ed.). Tehran, Eslamiyeh Publication.

Katouzian, N. (2001). Judicial acts (4th ed.). Tehran, Publication Corporate.

Katouzian, N. (2003). Civil Law (Family) (Vol. 1, 6th ed.). Tehran, Publication Corporate.

Katouzian, N. (2006). Civil Law at current order (13th ed.). Tehran, Mizan.

Katouzian, N. (2013). Civil Law, Lessons of specified contracts (19th ed.). Qanj-e-Danesh.

Khameneiee, S. M. (2006). Death from different point of view, Tehran, Human rights conference, the board of human rights in University of Beheshti.

Khansari, S. A. (1985). All documents in explanation of Brief of Al-Nafeh. Esmailiyeh Institute, Qom.

Qasemzade, S. M. (1996). Expansion of presumed death judgment and its problems, Legal Views Magazines, No. 1 st, Faculty of judicial science and bureaucratic services.

Safaee, H. (2008). Persons and Property (5th ed.). Tehran, Mizan Publication.

Safaee, H., \& Emami, A. (1998). Family Law (Vol. 1, 7th ed.). Tehran, University of Tehran Publication.

Safaee, H., \& Qasemzade, S. M. (2005). Civil Law, Persons and Incapacities (10th ed.). Tehran, SAMT publication.

\section{Copyrights}

Copyright for this article is retained by the author(s), with first publication rights granted to the journal.

This is an open-access article distributed under the terms and conditions of the Creative Commons Attribution license (http://creativecommons.org/licenses/by/4.0/). 